\title{
Civic agriculture in review: Then, now, and future directions
}

\author{
Allison Kaika ${ }^{a *}$ and Alexis Racelis ${ }^{b}$ \\ University of Texas Rio Grande Valley
}

Submitted August 13, 2020 / Revised October 26 and December 6, 2020 /

Accepted December 7, 2020 / Published online April 9, 2021

Citation: Kaika, A., \& Racelis, A. (2021). Civic agriculture in review: Then, now, and future directions. Journal of Agriculture, Food Systems, and Community

Development, 10(2), 551-572. https://doi.org/10.5304/jafscd.2021.102.030

Copyright (C) 2021 by the Authors. Published by the Lyson Center for Civic Agriculture and Food Systems. Open access under CC-BY license.

\begin{abstract}
"Civic agriculture," a term first coined by rural sociologist Thomas Lyson, refers to forms of agriculture that occur on a local level, from production to consumption, and are linked to a community's social and economic development. Sixteen years since its original articulation, the term "civic agriculture" has taken on greater significance in research, political activism, and community organizing. Grown from the roots of civic community theory, civic agriculture functions as a new branch of civic community theory that is ripe for theorization. In revisiting the foundations of the term, this review paper seeks to consolidate current and future research in the field of civic agriculture with a focus on its link to social welfare. This begins by reviewing the foundations of civic

\footnotetext{
a * Corresponding author: Allison Kaika, Masters Student, University of Texas Rio Grande Valley; 1201 West University Drive; Edinburg, TX 78539 USA; +1-704-515-4086; akaika4@gmail.com

b Alexis Racelis, Associate Professor, Department of Agricultural, Environmental and Sustainability Sciences, University of Texas Rio Grande Valley; 1201 West University Drive; Edinburg, TX 78539 USA; alexis.racelis@utrgv.edu
}

community theory and discussing how they influence research related to civic agriculture. As we report in this paper, there remain considerable gaps in understanding of how civic agriculture can be fomented by - or is related to-indicators such as demographics, concentration of power, community cohesion, and civic engagement. Consequently, the assumed links between local food systems and social welfare must continue to be studied to determine correlation and causality. This understanding is particularly important during this time of global pandemic, when the flaws and inequities of global supply chains are exposed and where, in many cases, civic agriculture met the increasing interest in local food. The COVID-19 pandemic has amply demonstrated the fragility and instability of global food supply chains, making the need for local food systems more significant and more relevant to communities across the world.

\section{Author Note}

This article is based on Allison Kaika's master's thesis.

\section{Funding Disclosure}

Allison Kaika was supported by the U.S. Department of Agriculture National Institute of Food and Agriculture National Needs Fellowship program, grant no. 2017-3842026758. 


\section{Keywords}

Civic Agriculture, Civic Community, Social

Welfare, Civic Engagement, Food Democracy, Local Food Systems

\section{Civic Agriculture in Review}

Over sixteen years ago, Thomas Lyson (2004) published his seminal book on "civic agriculture," tying together his and other scholars' work on the concept of a "civic community" 1 to formulate a term that encapsulates agriculture into the social and economic context of community. He and others drew from a body of knowledge around civic community theory, which posits a close connection between thriving locally oriented businesses and other demographic indicators to social welfare. ${ }^{2}$ Since then, there has been an ongoing application of civic community theory to explore connections between and among these indicators with agriculture and, in particular, with food systems embedded at the local level. This application has led to a new branch of study, civic agriculture theory, which has since been examined and tested in different scenarios with varying methodology.

This growing body of research has not only strengthened our understanding of food systems, but has also helped justify and inform the promotion of local food systems throughout the United States and elsewhere. These works have become particularly relevant in the context of both the COVID-19 pandemic and in light of the civil unrest related to racial inequity and injustice. These contexts have amply demonstrated the fragility and instability of global food supply chains and the systemic inequities in access to food and other basic services. This review provides a theoretical framework to analyze the accuracy and efficacy of the claims of civic agriculture theory, with a closer look at indicators described by various contributors to civic community theory. Studies employing demographic, civic engagement, community cohesion, and economic concentration ${ }^{3}$ indicators to demonstrate the positive effect of civic community on social welfare will be analyzed to better understand how civic agriculture shapes social welfare. Furthermore, this work closely considers research from both before and after the publication of Lyson's seminal piece to determine the theory's application in future research and public policy and to explore how it can further inform and strengthen our understanding of the relationship between farms, food, and community.

Food is not just a commodity; it is a determination of well-being and expression of social identity. Scholarly studies have demonstrated the positive effects of locally oriented businesses and manufacturers on social welfare, substantiating the claim that civic agriculture is also positively related to social welfare (Goldschmidt, 1978; Irwin \& Tolbert, 1997; Lyson, Torres, \& Welsh, 2001; Mills \& Ulmer, 1946; Lyson \& Tolbert, 1996; Tolbert et al., 1998; and more). Bringing light to these connections is a crucial step toward utilizing food systems to build just, equitable economies. Many studies have shown the relationship between civic agriculture, community involvement, activism, and empowerment. Nonetheless, further studies are needed to measure and confirm the direct relationship between civic agriculture and social welfare. A deeper understanding of the social impact of food systems is critical to building a stronger socio-economic fabric in the United States. Consequently, the purpose of this literature review is to systematically consolidate and analyze studies that document

\footnotetext{
1 Tolbert, Lyson, and Irwin (1998) discuss civic community in their article "Local capitalism, civic engagement, and socioeconomic well-being," in which they employ the term to describe the link between the performance of political institutions and the character of civic life.

2 Social welfare is a broad term that can encompass many aspects of a community's welfare. In order to maintain consistency and clarity throughout the paper, we will utilize the term social welfare as an umbrella term to refer to the specific aspects of social welfare analyzed across the studies reviewed, which include civic welfare, socio-political systems, community well-being, community cohesion, economic equality, and local capitalism.

${ }^{3}$ Economic concentration is a term utilized in civic community theory originally derived from Mills and Ulmer (1946), and further explored by Blanchard and Matthews (2006), who defined it as "(1) the concentration of employment into a small number of businesses; (2) the share of employment accounted for by non-local business owners; and (3) the industrial concentration of business activity" (p. 2247).
} 
the relationship between local food systems and community well-being. We utilize civic community theory as a framework to organize the studies that are material to civic agriculture theory and identify opportunities to better understand how civic agriculture shapes social welfare.

\section{Methodology}

For this literature review, we employed integrative review methodology to critique and synthesize the current state of literature available on civic agriculture (Torraco, 2005). The review is rooted in the original conceptualization of civic agriculture theory and its origins in civic community theory, and draws from more contemporary literature to document how civic agriculture theory has evolved in the last two decades (Snyder, 2019). Since civic agriculture theory is an adaption of civic community theory, it is important to determine whether studies on civic agriculture carried out after the formation of the theory affirm and operationalize civic community theory. We also use this review to offer opportunities for future study to strengthen both the theory and practice of civic agriculture.

We reviewed the canon of studies that have been conducted to identify and test possible indicators of civic community, and that are considered foundational in the development of civic community theory. From these papers, we created a comprehensive list of indicators employed by the authors to connect locally oriented businesses and manufacturers to social welfare, and aggregated this list into five categories: demographics, municipal services, concentration of power, community cohesion, and civic engagement (see Table 1). The civic community theory articles reviewed and divided into the five general categories are listed in Table 2.

To more systematically compare civic agriculture theory to civic community theory, we organized the five general indicators utilized across civic community theory studies (demographics, municipal services, concentration of power, community cohesion, and civic engagement) to include consequential published works on civic agriculture theory that refer to these indicators. To find these papers, we performed a comprehensive search of social, behavioral, political, and economic science peer-reviewed articles concerning civic agriculture theory using Web of Science, Google Scholar, and ProQuest databases, using the terms "civic agriculture," "local food" and/or "civic engagement," "civic community," and "food democracy." Articles referring to local food systems in relation to social welfare were added to our database of articles. Subsequently, the articles were reviewed for relevance to civic agriculture theory with a focus on the effect of local food systems on local, sociopolitical systems. From that subsequent database of articles, a targeted snowball search of literature from each article was performed in order to find any further relevant studies relating to the relationship between local food systems and social welfare.

These published works were then organized into the five categories of indicators aggregated from civic community theory studies in order to compare the indicators of civic agriculture theory

Table 1. Aggregated Civic Community Theory Indicators

\begin{tabular}{|c|c|c|c|c|c|}
\hline $\begin{array}{l}\text { Aggregated } \\
\text { Indicators }\end{array}$ & Demographics & $\begin{array}{l}\text { Municipal } \\
\text { Services }\end{array}$ & $\begin{array}{l}\text { Concentration } \\
\text { of Power }\end{array}$ & $\begin{array}{l}\text { Community } \\
\text { Cohesion }\end{array}$ & $\begin{array}{c}\text { Civic } \\
\text { Engagement }\end{array}$ \\
\hline \multirow{6}{*}{ 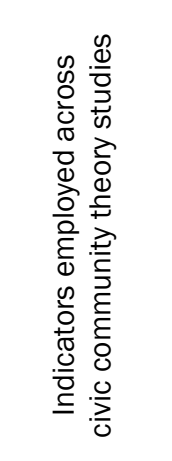 } & Employment & Sanitation & $\begin{array}{l}\text { Industrial } \\
\text { concentration }\end{array}$ & $\begin{array}{l}\text { Community } \\
\text { welfare }\end{array}$ & Voter turnout \\
\hline & Income & Number of parks & Unionism & Poverty & $\begin{array}{l}\text { Associational } \\
\text { membership }\end{array}$ \\
\hline & Education & $\begin{array}{l}\text { School } \\
\text { achievements }\end{array}$ & $\begin{array}{l}\text { Demographic } \\
\text { conformity }\end{array}$ & $\begin{array}{l}\text { Community } \\
\text { attitudes }\end{array}$ & Third places \\
\hline & Health indicators & $\begin{array}{l}\text { Recreation } \\
\text { opportunities }\end{array}$ & & Social capital & Volunteering \\
\hline & Religion & & & Crime & Civic activities \\
\hline & Home ownership & & & Nonmigration & \\
\hline
\end{tabular}


Table 2. Foundational Works in Civic Community Theory Examining Social Welfare

\begin{tabular}{|c|c|c|c|c|c|}
\hline Foundational Works & Demographics & $\begin{array}{l}\text { Municipal } \\
\text { Services }\end{array}$ & $\begin{array}{l}\text { Concentration } \\
\text { of Power }\end{array}$ & $\begin{array}{l}\text { Community Cohe- } \\
\text { sion }\end{array}$ & Civic Engagement \\
\hline Mills \& Ulmer (1946) & $\checkmark$ & $\checkmark$ & $\checkmark$ & & \\
\hline Fowler (1958) & $\checkmark$ & & $\checkmark$ & $\checkmark$ & \\
\hline Goldschmidt (1978) & $\checkmark$ & $\checkmark$ & & & \\
\hline Putnam (1994) & $\checkmark$ & & & $\checkmark$ & $\checkmark$ \\
\hline Lyson \& Tolbert (1996) & $\checkmark$ & & $\checkmark$ & $\checkmark$ & \\
\hline Irwin \& Tolbert (1997) & $\checkmark$ & & & $\checkmark$ & $\checkmark$ \\
\hline Tolbert, Lyson, \& Irwin (1998) & & & & & $\checkmark$ \\
\hline Irwin Tolbert, \& Lyson (1999) & & & & $\checkmark$ & $\checkmark$ \\
\hline Lyson, Torres, \& Welsh (2001) & $\checkmark$ & & $\checkmark$ & $\checkmark$ & $\checkmark$ \\
\hline Humphries (2001) & & & $\checkmark$ & & $\checkmark$ \\
\hline Tolbert, Irwin, Lyson, \& Nucci (2002) & $\checkmark$ & & & $\checkmark$ & $\checkmark$ \\
\hline Robinson, Lyson, \& Christy (2002) & & & $\checkmark$ & & \\
\hline Tolbert (2005) & & & & & $\checkmark$ \\
\hline Lyson (2006) & $\checkmark$ & & & $\checkmark$ & $\checkmark$ \\
\hline Blanchard \& Matthews (2006) & & & & & $\checkmark$ \\
\hline Lee (2008) & & & $\checkmark$ & $\checkmark$ & $\checkmark$ \\
\hline Lee (2010) & & & & $\checkmark$ & \\
\hline Lee \& Thomas (2010) & & & & $\checkmark$ & \\
\hline Blanchard, Tolbert, \& Mencken (2011) & $\checkmark$ & & $\checkmark$ & & \\
\hline
\end{tabular}

to the indicators employed to measure civic community theory. This integrative methodology allows for the identification of gaps in the current literature of civic agriculture theory as a subset of civic community theory (Torraco, 2005). Furthermore, it allows for the identification of variation between the theories that may need to be further studied. For example, we were not able to populate the category of municipal services indicators with civic agriculture literature. In our review we did not identify any studies of civic agriculture that look at municipal services as an indicator.

Of note, although there are diverse, and sometimes fraught, implications of the word "community" when used in reference to civic agriculture or civic community theory, we employ the term as is espoused in the work Tolbert (2005), who defines the term as an implied "focus that is bounded spatially and/or socially by a collective sense of place" (p. 1313).

A total of 159 papers were reviewed under the topics of civic community and civic agriculture theory. We present the results of this review in two parts. First, we distill the seminal works on civic community theory to identify the relevant indicators to apply to a burgeoning body of scholarship on civic agriculture theory. Then, we present the articles in our database determined most material to the topics of local food systems and social welfare. These articles are organized in the categories deduced from civic community theory article in the second part of this analysis in order to determine the current state of the theory and areas necessary for further study. 


\section{What is Civic Agriculture?}

In creating the theoretical framework for "civic agriculture," Lyson et al. (2001) make the connection between small, locally oriented production enterprises and their symbiotic success with community engagement and social welfare. ${ }^{4}$ Drawing from the literature on civic community theory, Lyson embeds the foundation of civic agriculture in socioeconomic theory. As defined by Lyson (2004), civic agriculture

is a locally organized system of agriculture and food production characterized by networks of producers who are bound together by place. Civic agriculture embodies a commitment to developing and strengthening an economically, environmentally, and socially sustainable system of agriculture and food production that relies on local resources and serves local markets and consumers. (p. 63)

At the foundation of civic agriculture is community problem-solving (Lyson, 2005). Due to the inherent focus at a local scale, the concerns of production, marketing, distribution, and food security are site-specific and thus are dependent on a community's ability to communicate, organize, and address these issues. This focus on civic problemsolving within community-oriented food systems integrates DeLind's (2002) depiction of civic agriculture with an emphasis on agriculture's ties to place. Not only does the generation of economic activity serve as a focal point of community wellbeing, but community ties, identity, and responsibility towards a place must also be integral to civic agriculture to create equitable development (DeLind, 2002).

As a branch of civic community theory, civic agriculture theory was initially developed from the government-commissioned studies of Mills and Ulmer (1946) and Goldschmidt (1978) out of concern for economic concentration. The U.S. Senate Small Business Committee commissioned both studies to analyze the impacts of large-scale indus- trial operations and farming organizations on local communities. Mills and Ulmer (1946) categorized three pairs of cities with similar demographic features but with different average business sizes. The study broadly concluded that small business cities offer a more balanced economic life and higher social welfare for citizens (Mills \& Ulmer, 1946). The authors hypothesized that urban centers with many small-scale operations depended on the community and other small businesses for their success, and, therefore, were inextricably linked to the community's well-being.

Following findings of Mills and Ulmer (1946), Dr. Walter Goldschmidt of the University of California at Los Angeles analyzed two agricultural communities in the industrialized specialty-crop hub of California's Central Valley. One was characterized by the presence of large farms in its area and the other by moderately sized farms. Goldschmidt (1978) found (1) the small-farm community supported more independent business establishments than the large-farm community; (2) residents of the small-farm community had a better average standard of living than those in the largefarm community; and (3) services, schools, parks, and civic organizations were more plentiful in the small-farm community. He concluded that largescale farms, which may have absentee owners, do not share common goals of community well-being and civic engagement with the local community.

Moreover, this theory has become increasingly relevant in recent years as the U.S. has seen both the percentage of small businesses and the percentage of the population employed by small businesses decrease significantly from 1993 to 2015 (U.S. Bureau of Labor Statistics, 2016). This may signal a downward trend in community well-being across the country. However, at the same time, the country has experienced tremendous growth in civic agriculture. For example, the number of registered farmers markets in the U.S. increased almost 400 percent over the same time period (U.S. Department of Agriculture Economic Research Service [USDA ERS], 2014). The extent of civic agri-

\footnotetext{
${ }^{4}$ The term "small" is utilized in this context in reference to independent ownership and number of employees in accordance with the U.S. Small Businesses Association definitions (U.S. SBA, 2019). However, there is no consensus in the definition of small businesses across the works presented in this review.
} 
culture's role in filling the void of civic enterprise has yet to be fully examined.

There have been some works that challenge the findings of civic community theory, and consequently, civic agriculture theory. A study in 1958 found cities with high concentration of industry, employment, and absentee ownership tended to have slightly higher welfare than those with the opposite characteristics (Fowler, 1958). However, the study was conducted in only one state with different measurements of small versus large businesses and social welfare than those utilized by Mills and Ulmer (1946). Hayes and Olmstead (1984) laid out an important critique of Goldschmidt (1978), pointing out that there were factors such as development timeline and natural resources that may have also affected land prices. Nonetheless, the authors did not replicate a study to disprove the findings with new methodology, so it cannot be confidently discredited.

More recently, Humphries (2001) found that self-employment was the strongest indicator of community engagement, but also that individuals who reside in communities with fewer independent business owners are not less politically engaged than those who do. These findings are interesting to further explore as they display contradicting results to the prevailing works in civic community theory. Although commuting is negatively associated with political participation, and self-employment is positively associated, the concentration of independent or retail establishments does not have a statistically significant effect on political participation. Different indicators of locally oriented businesses exhibit varying results on political participation. Consequently, although providing important criticisms of the foundational literature, these studies cannot conclusively discredit the cumulative body of work on civic community theory.

\section{Origins of Civic Agriculture Theory}

After a shift away from studies of small businesses and social welfare in favor of industrialization, a surge of research emerged under the seminal works of Mills and Ulmer (1946) and Goldschmidt (1978). Working under the shadow of globalization, a handful of academics concerned with community-based social welfare outcomes deliberated these concepts of large versus small, local versus global, concentrated versus distributed. These studies examined the emerging idea that that locally facing, small businesses and manufacturers have a positive relationship with social welfare. Rather than proposing free-market neoliberalism as the path for economic development, civic community theory argues that the public domain is more significant than individual self-interest and that the strength of a community lies in its institutions that mediate social capital (Lyson \& Tolbert, 2003).

One of the first works to articulate the relationship between business size and social welfare came from Piore and Sabel (1984), who assert that craft manufacturing fills a gap in product markets that are rejected by mass producers. Craft manufacturers are able to produce artisan and specialty products for which there is not a high enough demand to mass produce and may only be desired in a specific place. Therefore, despite the industrialization of the U.S. economy during and after both World Wars and amid a shift toward globalization, small businesses have remained a constant and growing part of the U.S. economy and provide an important source of stability in communities. Craft or specialty goods fill a hole in the market for those who are seeking out an alternative to the industrial system, one that is based in place and history. Robinson et al. (2002) found that community economies represented by local, craft production that is locally operated and independently owned were positively associated with social welfare when compared with community economies that center around globalization and mass production.

In succeeding studies of business size, Lyson and Tolbert (1996) conducted an analysis of 2,235 nonmetropolitan counties to determine both the impacts of small (15-25 workers) and large ( $>250$ workers) manufacturers on socio-economic wellbeing to conclude that although the data demonstrated some positive effects of large manufacturing establishments, such as lower inequality, the presence of small manufacturing is associated with lower poverty rates and higher income levels. In the same vein, Tolbert et al. (1998) measured the number of associations, small manufacturing establishments ( $<20$ workers), and third places-locations that people can gather and socialize (e.g., pubs, cof- 
fee shops, barber shops, etc.)—and compared them to social welfare indicators (Oldenburg, 1991). Their findings indicate that although local capitalism indicators had negative effects on inequality, demographic indicators, such as education, were a more accurate prediction of socioeconomic well-being. Findings also revealed that small businesses are associated with decreased migration, lower unemployment, and reduced income inequality. More recently, Rupasingha (2017) found evidence that microbusinesses are associated with local income growth, but not enough to claim causal effects.

Tolbert et al. (2002) employed the unit of small towns (2,500-20,000 residents) to measure the number of businesses and third places against social welfare indicators. Their results showed that the number of self-owned and -operated businesses and third places is positively associated with social welfare in both metro and non-metro small towns. They also found that towns with a higher number of small, independently owned businesses and an abundance of public meeting spaces had higher levels of social welfare, defined by higher median income, lower poverty rates, nonmigration, and lower unemployment. Lyson (2006) followed this work with a test of Mills and Ulmer's (1946) study, examining 25,000 manufacturing-dependent counties and discovered that counties with an economy organized around smaller-scale enterprises ( $<1,000$ workers) were associated with more favorable social welfare measurements-including an economically independent middle class, less economic inequality, higher education outcomes, and lower crime rates-when compared to counties organized around large-scale corporations (>1,000 workers).

Studies show that civically engaged communities are associated with lower incidences of violent crime and all-cause mortality in counties across the country (Lee, 2008, 2010; Lee \& Thomas, 2010). Similarly, an analysis of population health in relation to business size in 3,060 U.S. counties found that the presence of large retailers has a detrimental effect on age-adjusted rates of mortality and the presence of obese adults (Blanchard, Tolbert, \& Mencken, 2011). Of note, race is glaringly absent as a variable of differentiated analysis. Targeted studies with a focus on race as an indicator, rather than a control, will be important to carry out in regard to the effects on civic community.

Along with health indicators, crime rates, and income, nonmigration is also used as an indicator of civic community richness. The longer one lives in a community, the higher likelihood they have of holding a larger number and diversity of social ties (Tolbert, Mencken, Blanchard, \& Li, 2016). Studies have found that counties and states with higher numbers of small manufacturing, retail firms, and civic associations have lower levels of migration (Irwin \& Tolbert, 1997; Irwin, Tolbert, \& Lyson, 1999; Stroope, Franzen, Tolbert, \& Mencken, 2017). Self-employment has also been demonstrated as an indicator of civic engagement. Business owners have a greater stake in the local community and invest accordingly (Mencken, Smith, \& Tolbert, 2020). Alternatively, economic concentration is negatively correlated with electoral politics and protest activities, pointing to lower civic participation in areas of high economic concentration (Blanchard \& Matthews, 2006).

When examining how agricultural enterprises affect social welfare, Lyson et al. (2001) measured the relationship between the scale of farming operations and the social welfare of residents. They found that agriculturally dependent counties with a high percentage of residents who operate small, commercial businesses and are civically engaged have higher levels of social welfare. ${ }^{5}$ They posit that the presence of a strong middle class with high levels of civic engagement is associated with relatively higher levels of social welfare in an agricultural county. Furthermore, activities of civic agriculture have an association with the specific social, economic, and demographic characteristics of the communities they serve (Lyson \& Guptill, 2004), especially in comparison to activities centered on commodity agriculture. The prevalence of civic versus commodity agriculture within a county has profound effects on the communities in which they

\footnotetext{
${ }^{5}$ Lyson et al. (2001) define "agriculturally dependent counties" as counties with at least 75 percent of land in farming and at least 50 percent of gross county sales in agricultural goods and services.
} 
are present, either bolstering civic growth and social capital, or pushing toward a more globalized and concentrated system (Besser, 2009).

In an effort to explore the significance of localversus global-facing firms on social welfare, Tolbert (2005) measures how locally oriented establishments affect civic behaviors, such as associational membership, visitation to local retail establishments, and voting habits. When controlling for state median income and population, he found that the locally oriented establishments are positively associated with small manufacturing establishments, associations, public gathering places, and voter turnout. Furthermore, locally oriented establishments were found to have negative correlations with rates of poverty, infant mortality, and crime, although authors can only determine correlation and not causation.

More recently, Clark and Record (2017) studied the levels of civic engagement of local farm owners to determine if there was a significant difference between owners whose farms were locally facing, or community-oriented and selling to local customers, compared to owners whose farms were utilizing intermediating markets or were globally oriented. The results demonstrated that owners of locally facing farms were more engaged both civically and politically. These findings display the impact of globalized markets on a community's civic engagement. When the end-consumer of a firm's product is not in the community, the owner and the business's model do not depend on the wellbeing of the community, and the firm can be less invested in the community. On the other hand, locally facing firms are dependent on the community and have a direct stake in community matters; therefore, they are more likely to engage.

Despite the original authors utilizing municipal services as an indicator of social welfare, no proceeding authors followed suit. Lyson (2006) employed municipal services only as he replicated Mills and Ulmer's (1946) original study. Although it is unknown why municipal services were not considered significant to pursue in further studies, it may be an indicator that should be analyzed in future studies to reveal more robust findings to strengthen civic community theory.

Through the aforementioned studies, this canon of literature has served as a foundation of civic agriculture theory. We break down the main concepts and indicators related to social welfare in Table 2. In the remainder of the paper, we explore how these indicators intersect with civic agriculture in order to corroborate how, as a branch of civic community theory, civic agriculture relates to various indicators of social welfare.

\section{Concentration of Power}

\section{Civil Society and Community Capitalism}

Since proponents of civic agriculture have theorized that the economic benefits claimed in civic community theory apply correspondingly, researchers have set out to corroborate the assertion at the community level. Based on findings in civic community theory, there is an expectation that a decentralization of economic and social power inherent in the proliferation of small, independent businesses will result in more equal distribution of wealth and power. In civic agriculture studies, researchers have honed in on farmers markets as a manifestation of business diversity and as spaces for entrepreneurship, business innovation, market research, enterprise diversification, and business incubation (Cameron, 2007; Feenstra, Lewis, Hinrichs, Gillespie, \& Hilchey, 2003; Gillespie, Hilchey, Hinrichs, \& Feenstra, 2006; Hinrichs, Gillespie, \& Feentra, 2004; O’Hara \& Coleman, 2017). Farmers markets create a unique and visible place for small businesses and community members to test new ideas, generate feedback, and learn from other vendors. They also have direct economic impact on the downtown areas of towns and cities. Shoppers who would normally not visit the downtown area or frequent the stores are drawn to the market, which results in increased sales for neighboring businesses (Abel, Thomson, \& Maretzki, 1999; Lev, Brewer, \& Stephenson, 2003; Swenson, 2009).

Brown (2002) reported evidence that in the district of the farmers markets, property values increased. Of note, this can lead to concerns of gentrification if those located near the market are not also economically benefiting from its placement. At the same time, reverberating economic benefits may increase the amount of capital available to lo- 
cal residents and local governments to invest in community well-being. Another form of civic agriculture, community gardens, has also proved to increase property values, augment community confidence and safety, and increase the availability of fresh produce in lower-income and racially diverse areas (J. Allen, Alaimo, Elam, \& Perry, 2008; Sullivan, Kuo, \& DePooter, 2004).

In an overview of trends in local food systems in the United States, Low et al. (2015) discuss the overarching impact of local food systems on the U.S. agricultural landscape and economy. The authors found an economic ripple effect in communities where food is purchased locally. A report by the U.S. Department of Agriculture Economic Research Service found that fruit and vegetable farms selling into local and regional markets employ 13 full-time workers per US $\$ 1$ million in revenue earned, compared to the three full-time workers per US $\$ 1$ million in revenue earned by fruit and vegetable farmers selling elsewhere (Low \& Vogel, 2011). Local food production creates skilled, higher-paying employment opportunities, which could indirectly increase household spending (Bauman, Jablonski, \& Thilmany McFadden, 2019; Rossi, Johnson, \& Hendrickson, 2017; Shideler, Bauman, Thilmany, \& Jablonski, 2018). However, it is important to point out that most local farm sales occur on the East and West Coasts in urban areas.

In Europe, farm-to-school programs have been found to increase opportunity for suppliers and contribute profit to the overall economy (Sonnino, 2013). In a case study of Hardwick, Vermont, known as "the town that food saved," Olson (2019) found that the increase in small agriculture related-businesses coincided with a decrease in poverty rates and unemployment. Although the economic impact is not the sole concern of civic agriculture components, it may play a role in producing economically stable, equitable communities-contributing to the creation of small, locally oriented businesses and an independent middle class.

Nonetheless, scholars and practitioners still debate whether local food production is a viable business venture-as the majority of farms struggle, economies of scale may be the most profitable for the individual farm (Deller, Lamie, \& Stickel, 2017). Overall social welfare may benefit more from place-based food production. These findings suggest that local and regional food systems have a significant economic benefit on their communities. Local food businesses stimulate the economy, create jobs, and invest money spent back into the community, signaling a significant opportunity for local governments to invest in community development through local food systems (Bauman et al., 2019; Rossi et al., 2017; Shideler et al., 2018; Sonnino, 2013).

\section{Place and Market}

One of the hallmark components of civic agriculture is the connection to place. Orientation toward local customers and local demands builds personal relationships (Lyson, 2004). The social connections and economic exchanges of civic agriculture are intertwined, embedding agriculture into the community. Small farmers are dependent on their specific knowledge of place: the earth, the resources, and the people. Cultivation of food locally has the potential to embed consumers into their geographic place, creating an identity associated with community (Cone \& Myhre, 2000).

However, several authors have warned against these claims as a "local trap," otherwise termed as "defensive" or "unreflexive" localism $J$. Allen et al., 2008; P. Allen, 1999, 2010; Born \& Purcell, 2006; DeLind \& Bingen, 2008; DuPuis, Goodman, \& Harrison, 2006; Hinrichs, 2003; Mount, 2012). In critiques of civic agriculture, the preoccupation with the "local" is seen as a toothless solution to the neoliberal, global marketplace which does not address the foundations of individualism and profit-driven markets that create inequality and injustice (P. Allen, FitzSimmons, Goodman, \& Warner, 2003; Guthman, 2011; Hinrichs, 2000; Jarosz, 2011; Kirwan \& Maye, 2013; O’Hara \& Stagl, 2001). Furthermore, other scholars are concerned that civic agriculture may be inaccessible and exclusive to parts of the population based on race, class, and location (Alkon \& McCullen, 2011; P. Allen, 2010; Godette, Beratan, \& Nowell, 2015; Guthman 2003, 2008). Without a grounding in place or focus on community, civic agriculture tends to concentrate less on culture and social ties 
and more on market functions (DeLind, 2002; Hinrichs, 2000). Local, direct-market agriculture in itself is market-based. It does not inherently address issues of social injustice. Consequently, 'reflexive localism' implies maintaining vigilance about potential injustices that could arise at the community level in a 'localized' system (DuPuis et al., 2006). Purchasing local food may not inherently prompt consumers to question inequality or to get involved in their community. It must also change the meaning of consumption to create change (Johnston, 2008; Ostrom, 2008). A robustly contextualized understanding of place that is accompanied by community responsibility to equitable community priorities is pivotal to truly embed a food system in the social well-being of a community.

In their discussion of global versus alternative food markets, O'Hara and Stagl (2001) and Hinrichs (2000) make important theoretical connections between the economic market and physical place. The authors highlight how a globalized food system is socially and environmentally "disembedded"6 from its place and people of origin. Alternatively, civic agriculture brings a value, quality, and craft to food that can only be created with an understanding of place (Barbera, Dagnes, \& Di Monaco, 2020; Chiffoleau, Millet-Amrani, Rossi, Rivera-Ferre, \& Merino, 2019; Wittman, Beckie, \& Hergesheimer, 2012). These social ties can be part of what a producer is selling in a market.

Nonetheless, production and consumption cannot necessarily be equated with social ties and civic engagement. DeLind (2002, 2011) cautions that civic agriculture must be applied in a way that incorporates the common good of the greater community over the market interests of the individual. Moreover, market and politically centered strategies cannot lead to the social outcomes local food systems espouse to engender; the community itself must be supported. Civic agriculture can provide the setting for this type of embedding in place and community, vis-à-vis education and policy that support these practices. The production and consumption of a local product in the same physical space offers a promising unification of market exchange with identity and what DeLind and Bingen (2008) call "placed"-ness (Trivette, 2017). This is an example of what some authors argue is reflexive or adaptive localism (Crossan, Cumbers, McMaster, \& Shaw, 2016; DuPuis \& Goodman, 2005; DuPuis, et al., 2006; Ross, 2006). In other words, the inherent diversity and complexity within a community is reflected in its civic agricultural markets, relationships, and networks, and recognized as a continually evolving piece in the political process (Hasanov, Zuidema, \& Horlings, 2019; Schnell, 2016). Awareness of the realities of neoliberalism, individualism, and exclusion serves as the means toward building a successful and equitable civic agriculture landscape (Tornaghi, 2016).

The reflexivity and adaptability of communities help strengthen civic agriculture markets by embedding social capital into market relationships (Flora \& Bregendahl, 2012; Schnell, 2013). Bunkus Soliev, and Theesfeld (2020) demonstrate that a community's relationship to agriculture is stronger when the density of resident farmers is higher. The authors also found that where there is a greater presence of farms in rural areas, residents describe a more significant attachment to place. In general, locally oriented agriculture plays an important role in strengthening social capital, including social embeddedness, sense of belonging, and access to information (Besser, 2009; Flora \& Bregendahl, 2012; Furman, Roncoli, Nelson, \& Hoogenboom, 2014; Schmit, Jablonski, Minner, Kay, \& Christensen, 2017; Schnell, 2013).

Civic agriculture activities must be mindfully cultivated to create accessible space for marginalized groups. For example, some community supported agriculture (CSA) programs and markets prioritize low-income residents, while certain gardens and farms intentionally bring marginalized groups into civic folds and social networks of a community (J. Allen et al. 2008; Baker, 2004; Cumbers, Shaw, Crossan, \& McMaster, 2018; Poulsen, 2017; Smit \& Bailkey, 2006). Participation in civic agriculture allows individuals to explore the poten-

\footnotetext{
${ }^{6}$ Polanyi $(1944,1957)$ was one of the first to use the term disembedded to describe economic markets where production techniques, knowledge systems, and ecological attributes that create a product in a specific place, become increasingly homogenous and devoid of those specificities in a global market.
} 
tial of collective power (Canal Vieira, Serrao-Neumann, \& Howes, 2019; Siegner, Acey, \& Sowerwine, 2020), or it can create the chance to regain agency and power in the community (Alkon, 2008; Bornemann \& Weiland, 2019; Bradley \& Galt, 2014). By creating the conditions under which knowledge, networks, and awareness can be cultivated, civic agriculture can generate both community and social capital. That said, the true impact of civic agriculture on the redistribution of power and resources remains relatively unexplored, and in some cases can consolidate power within a select few. This reveals the need for specific and intentional engagement of marginalized groups to access, deploy, and create new and existing community networks to successfully build civic agriculture in their communities.

\section{Community Cohesion}

\section{Cultivating Social Capital}

Whether it is starting a new business in a community, establishing a farm, soliciting membership for a CSA, or cultivating a community garden, civic agriculture promotes the growth of social networks as people's paths cross and connect in ways they would not have before. In creating direct-to-consumer businesses for local food, farmers and entrepreneurs are dependent on a host of organizations, individuals, and government sectors to be successful (Canal Vieira et al., 2019; Christensen \& Phillips, 2016; Cvijanović, Ignjatijević, Tankosić, \& Cvijanović 2020; Hasanov et al., 2019; Hughes \& Isengildina-Massa, 2015; Janssen, 2010). Civic agriculture addresses community issues such as rural revitalization, food availability, and social welfare, if built on a foundation of strong networks and interpersonal transaction (J. Allen et al., 2008; Bagdonis, Hinrichs, \& Schafft, 2009; Renting, Marsden, \& Banks, 2003). At urban farms, gardens, and CSA gatherings, participants find a shared sense of belonging, nurturing the growth of community cohesion, and vocalize its significance (Dunlap, Harmon, \& Camp, 2020; Firth, Maye, \& Pearson, 2011; Kingsley, Foenander, \& Bailey, 2019; Macias, 2008; Sumner, Mair, \& Nelson, 2010). It is that desire for social embeddedness and a sense of community that drives many farmers to participate in civic agri- culture (Migliore, Caracciolo, Lombardi, Schifani, \& Cembalo, 2014). In fact, direct-to-consumer farms are dependent on strong farmer-consumer relationships to be successful (Poulsen, 2017).

Not only do network connections foment social integration, but they also create empowerment through the collective sharing of knowledges and individual learning. Gardeners learn new skills, farmers learn to engage their community, volunteers learn to organize, and a broader sense of resources available in the local community is brought to the attention of all involved (Kingsley et al., 2019; Liu, Gilchrist, Taylor, \& Ravenscroft, 2017; Prost, 2019; Trauger, Sachs, Barbercheck, Brasier, \& Kiernan, 2010). Farmers who engage in civic agriculture are dependent on mutual education with consumers to demonstrate the importance of their craft and receive feedback on their work. These exchanges are shown to increase participation and retention of customers, as well as further their own innovation (Hinrichs et al., 2004; Ross, 2006). Schmit et al. (2017) reveal an increased flow of intellectual capital to rural areas through the networks of local food systems. This original knowledge creates a more robust network and resilience, in which a community is more equipped to address certain problems with newfound social capital (Furman et al, 2014). In that notion of place, the physical space of a farm, garden, or market can become a missing space where community members have an opportunity to meet, work together, and socialize (Firth et al., 2011; Liu et al., 2017; Trauger et al., 2010).

Small, community-oriented farms, gardens, and markets seek to create a space where community members can gather and be considered as contributing to something greater than oneself (Bingen, Sage, \& Sirieix, 2011; Chung, Kirkby, Kendell, \& Beckwith, 2005; Cox et al., 2008; Flora \& Bregendahl, 2012; Poulsen, 2017; Sharp, Imerman, \& Peters, 2002). Onozaka, Nurse, and Thilmany (2010) found that consumers who bought directly from farmers felt a larger sense of community in being influenced by others buying practices around them (Low et al., 2015). Moreover, they overwhelmingly felt that their actions "make a difference" for both public and private outcomes (Low et al., 2015), fomenting a sense of personal and 
civic efficacy. Civic participation in agricultural systems has been shown to not only to expand the civic imagination of participants to consider issues and opportunities in the community that had not been evident before (Cox et al., 2008, Schugerensky, 2003), but also to create an opportunity for community involvement that connects to the larger community social welfare (J. Allen et al., 2008; Niewolny et al., 2012).

\section{Food Democracy and Citizenship}

The opportunity for community involvement generates an avenue for individuals to practice civic engagement. Participation in civic agriculture can serve as a form of exercising one's right to engage in community issues. Lang (1999) captured this concept with the notion of "food democracy," which entails individuals taking an active role in food procurement, such as identifying and seeking out local food sources. Hassanein (2003) proposes food democracy as a step toward social, economic, and ecological justice, while relying heavily on residents' participation and engagement (Lyson, 2005) to empower individuals and communities. There is a concurrence that an active attitude of responsibility among community members and within individuals is the cornerstone of more equitable agro-food systems (Cumbers et al., 2018; Kingsley et al., 2019; Levkoe, 2006; Renting, Schermer, \& Rossi, 2012).

Shopping at a farmers market, volunteering at a CSA, or working in a community garden can change a relationship from solely customers to active consumers, and can allow individuals to reclaim the opportunity to shape their community (Bródy \& deWilde, 2020; Crossan et al., 2016; Hasanov et al., 2019). Marginalized groups are able to find their place and voice in communities through the cultivation of gardens and the act of occupying physical space (Baker, 2004; SaldivarTanaka \& Kransy, 2004). Efforts to re-orient the agricultural market to local needs offer consumers the opportunity to increase awareness around community issues and become active to address them (Cox et al., 2008; McIvor \& Hale, 2015; Schugerensky, 2003). Furthermore, by recognizing the role of the individual and the collection of community members in food systems, people are empowered to turn to collective, community action to problem solve and look beyond the formal governing body as the responsible figure for community well-being (Baker, 2004; Dunlap, Harmon, \& Camp, 2020; DuPuis \& Gillon, 2009). In some cases, it can inspire people to consider their involvement as a gesture of activism to reject the industrialized food system (Macias, 2008; Schnell, 2010).

\section{Demographics}

\section{Barriers to Civic Agriculture}

Many practitioners and scholars of local food systems have expressed continued concern about whether the success and benefits of civic agriculture are predetermined by demographics, and in particular, race, income, gender, and education (see, among others, Alkon \& McCullen, 2011; P. Allen, 2010; Colasanti, Conner, \& Smalley, 2010; Guthman, 2008). Studies over the years documenting the demographics of participants in civic agriculture reveal mixed findings. Overall, studies of CSAs (Cone \& Myhre, 2000; Lass, Bevis, Hendrickson, \& Ruhf 2001; Ostrom, 2008; Schnell, 2010), farmers markets (Alkon \& McCullen, 2011; Byker, Shanks, Misyak, \& Serrano 2012; Cvijanović et al., 2020; Wolf \& Berrenson, 2003) and local food sales (Feldmann \& Hamm, 2015; Godette et al., 2015; Martinez et al., 2010; O'Hara \& Low, 2016; Thilmany, Bond, \& Bond, 2008) show that participants tend to be white, wealthy, female, and college-educated, and are generally located in the Northeastern U.S. or West Coast near a metropolitan area. Although indicators of wealth and social class (such as proximity to a farmers market or a flexible work schedule) are often associated with greater access to local food, (Abelló, Palma, Anderson, \& Waller, 2014; Galt et al., Bradley, Christensen, \& Munden-Dixon, 2018; McGuirt et al., 2014; Zepeda \& Nie, 2012), some scholarship posits that these demographics are not the only driver of local food consumption patterns (Guptill, Larsen, Welsh, \& Kelly, 2018; Thilmany et al., 2008; Galt et al., 2017; Galt, Bradley, Christensen, \& MundenDixon, 2019). Rather, ideological and emotional considerations should also be considered as potentially stronger indicators than demographics (Beagan, Power, \& Chapman, 2015; Lombardi, Migliore, Verneau, Schifani, \& Cembalo, 2015; 
Zoll, 2018). In certain areas, people of diverse socioeconomic backgrounds solicit farmers markets (Sadler, Gilliland, \& Arku, 2013). Although demographic indicators undoubtedly play an important role, race, income, education, and others have not been proven to be the conclusive determinants of civic agriculture involvement.

Tegtmier and Duffy (2005), among others, found that farmers who start CSAs or sell direct to consumer tend to be college-educated, middleaged, and are located on the East or West Coast. These farms tend to be small, and cultivated with organic, biodynamic, or ecosystem-focused practices (Lass et al., 2001; Wells \& Gradwell, 2001). A noticeable income gap has been observed between the producers and the consumers of local food (Ostrom, 2008; Schnell, 2010). Most farmers struggle to stay afloat financially and to keep members coming back every season (Ostrom, 2008; Schnell, 2010). These factors may reduce the type of farmers and residents participating in local food systems to a specific subset, limiting the impact of civic engagement and community building to a certain socio-economic group. Godette et al. (2015) points out that the contextual factors surrounding a community must be considered in creating a local food system - not only demographics, but also geography, infrastructure, and markets. Farmers are often more dependent on their relationships with the consumers than consumers are on farmers (Ostrom, 2008). This creates an unhealthy power balance that can cause farmers financial and social distress.

Indicators such as religiosity and social views are underexplored indicators of civic agriculture. There remains a dearth of research of the role that faith-based member organizations such as churches can have in facilitating engagement of its members or employees in civic agriculture. For example, instances of civic agriculture mediated by church leaders and congregations exist across the U.S., but are uncommonly documented and analyzed as a way to strengthen relationships between consumers and farmers. Often farm-to-institution programs rely on the farmer mediating the relationship with consumers, but leaders or administrators in these organizations can play an instrumental role in influencing the success of these initiatives by substanti- ating other incentives or rationale for participating and benefiting from civic agriculture. For example, faith-based organizations can inject other considerations for individual or community participation in civic agriculture, such as stewardship, giving, or other principles central to that religion.

\section{Civic Engagement}

The hypothetical connections between civic agriculture and civic engagement have been thoroughly assessed, albeit through indirect means. Only a handful of studies have attempted to directly examine the relationship. Both Obach and Tobin (2014) and Carolan (2017) produced studies demonstrating that individuals engaged with civic agriculture tend to have increased levels of civic engagement compared to community members who only utilize conventional food systems. Obach and Tobin (2014) found consumers in New York state engaged in civic agriculture tend to also be more politically engaged and willing to volunteer than those who do not participate in civic agriculture. Carolan (2017) conducted a longitudinal study comparing the civic engagement of alternative and conventional eaters in Colorado and found that individuals who participate in civic agriculture are more likely to be active citizens in their community than conventional eaters. Though the values of civic engagement may already be inherently present in participants of civic agriculture, Carolan (2017) found that continued practice in civic agriculture can strengthen those beliefs.

Pole and Gray (2013) distributed a survey to CSA members in New York state to measure levels of community engagement in relation to their CSA experience. Contrary to previous research, they found that CSAs do not necessarily generate or promote a sense of community among members. However, respondents displayed a high level of civic participation either at the CSA or within their community. Clark and Record (2017) studied the levels of civic engagement of local farm owners to determine if there was a significant difference in owners whose farms were community-oriented and were selling to local customers, compared to owners whose farms were utilizing intermediating markets or were globally oriented. The results demonstrated that owners of locally facing farms were 
more likely to be engaged both civically and politically than their counterparts. Collectively, these studies document a correlation between civic agriculture and civic engagement but none effectively addresses the issue of causality. There may be even be a mutually re-enforcing effect between civic agriculture and civic engagement, warranting further study of this relationship.

\section{Conclusion}

All the work included in this review shares the view that food-from its production to its consumption-is a product of complex environmental and social interactions. These interactions can be at multiple scales that range from locally grown and locally consumed food to food that is globally traded and sold. For many, access to food is not only a determinant of well-being, but it is also an expression of social identity. In this work, we consolidate the wealth of scholarship that has demonstrated the positive effects of the former (locally grown and locally consumed food) on community well-being as a crucial, empirically grounded foundation toward utilizing food systems to build just, equitable economies. In addition, the many studies presented here illustrate the relationship between civic agriculture, community involvement, activism, and empowerment, and can be used to inform a roadmap to instill placed-ness in food systems that yield obvious and immediate benefit to communities at a local scale.

This work also identifies significant gaps in our understanding of the connection of municipal services and the role of institutions in civic agricul- ture, as well as a need to better elucidate the direct relationship between civic agriculture and civic engagement. The connection of these concepts to civic agriculture remains unclear and underexplored. We encourage both practitioners and scholars to help uncover these deficiencies through experience and exploration, as they may be key to improving the benefits of civic agriculture, especially in rural, low-income, and racially diverse communities. However, the collective evidence presented here reveals a clear association between civic agriculture and social welfare, both rural and urban, through increased social capital, embedded community-based economies, and as an outlet for civic engagement and political empowerment. In order to increase democratic engagement and build stronger communities, local governments, organizations, and individuals should explore supporting civic agriculture as a means to increase social welfare.

\section{Acknowledgements}

Thank you to the United States Department of Agriculture National Institute of Food and Agriculture National Needs Fellowship program, which made this research possible. A sincere thank you to Dr. Owen Temby, Dr. William Donner, and Dr. Dongkyu Kim at the University of Texas Rio Grande Valley for their guidance, support and feedback for the conceptualization and original drafts of this paper. Thank you to the anonymous reviewers who provided insightful and meaningful suggestions to this paper, significantly improving its structure.

\section{References}

Abel, J., Thomson, J., \& Maretzki, A. (1999). Extension’s role with farmers' markets: Working with farmers, consumers, and communities. Journal of Extension, 37(5), 47-58. Retrieved from https://archives.joe.org/joe/1999october/a4.php

Abelló, F. J., Palma, M. A, Anderson, D. P., \& Waller, M. W. (2014). Evaluating the factors influencing the number of visits to farmers' markets. Journal of Food Products Marketing, 20(1), 17-35. https://doi.org/10.1080/10454446.2013.807406

Alkon, A. (2008). Paradise or pavement: the social constructions of the environment in two urban farmers' markets and their implications for environmental justice and sustainability. Local Environment, 13(1), 271-289. https://doi.org/10.1080/13549830701669039

Alkon, A. H. and McCullen, C. G. (2011). Whiteness and farmers markets: Performances, perpetuations... contestations? Antipode, 43(4), 937-959. https://doi.org/10.1111/j.1467-8330.2010.00818.x 
Allen, J. O., Alaimo, K., Elam, D., \& Perry, E. (2008). Growing vegetables and values: Benefits of neighborhood-based community gardens for youth development and nutrition. Journal of Hunger and Environmental Nutrition, 3(4), 418-439. https://doi.org/10.1080/19320240802529169

Allen, P. (1999). Reweaving the food security safety net: Mediating entitlement and entrepreneurship. Agriculture and Human Values, 16(2), 117-129. https://doi.org/10.1023/A:1007593210496

Allen, P. (2010). Realizing justice in local food systems. Cambridge Journal of Regions, Economy and Society, 3(2), $295-308$. https://doi.org/10.1093/cjres/rsq015

Allen, P., FitzSimmons, M., Goodman, M., \& Warner, K. (2003). Shifting plates in the agrifood landscape: The tectonics of alternative agrifood initiatives in California. Journal of Rural Studies, 19(1), 61-75. https://doi.org/10.1016/S0743-0167(02)00047-5

Bagdonis, J. M., Hinrichs, C. C., \& Schafft, K. A. (2009). The emergence and framing of farm-to-school initiatives: Civic engagement, health and local agriculture. Agriculture and Human V alues, 26(1), 107-119. https://doi.org/10.1007/s10460-008-9173-6

Baker, L. E. (2004). Tending cultural landscapes and food citizenship in Toronto's community gardens. Geographical Review, 94(3), 305-325. https://doi.org/10.1111/j.1931-0846.2004.tb00175.x

Barbera, F., Dagnes, J., \& Di Monaco, R. (2020). Participation for what? Organizational roles, quality conventions and purchasing behaviors in solidarity purchasing groups. Journal of Rural Studies, 73(2020), 243-251. https://doi.org/10.1016/j.jrurstud.2019.10.044

Barnes, W. R. (2010). Governing cities in the coming decade: The democratic and regional disconnects. Public Administration Review, 70(Suppl. 1), 137-144. https://doi.org/10.1111/j.1540-6210.2010.02256.x

Bauman, A., Jablonski, B. B. R., \& Thilmany McFadden, D. (2019, June). Exploring the underlying economics of local food producers: Opportunities for rural economic development. Presentation at the Agricultural and Applied Economics Association 2019 Annual Meeting, Atlanta, Georgia. https://doi.org/10.22004/ag.econ.291295

Beagan, B. L., Power, E. M., \& Chapman, G. E. (2015). "Eating isn’t just swallowing food”: Food practices in the context of social class trajectory. Canadian Food Studies / La Revue Canadienne Des Études Sur l'alimentation, $2(1), 75$. https://doi.org/10.15353/cfs-rcea.v2i1.50

Besser, T. L. (2009). Changes in small town social capital and civic engagement. Journal of Rural Studies, 25(2), $185-193$. https://doi.org/10.1016/i.jrurstud.2008.10.005

Bingen, J., Sage, J. \& Sirieix, L. (2011). Consumer coping strategies: A study of consumers committed to eating local. International Journal of Consumer Studies, 35(4), 410-419. https://doi.org/10.1111/j.1470-6431.2010.00949.x

Blanchard, T., \& Matthews, T. L. (2006). The configuration of local economic power and civic participation in the global economy. Social Forces, 84(4), 2241-2257. https://doi.org/10.1353/sof.2006.0080

Blanchard, T. C., Tolbert, C., \& Mencken, C. (2011). The health and wealth of US counties: How the small business environment impacts alternative measures of development. Cambridge Journal of Regions, Economy and Society, 5(1), 149-162. https://doi.org/10.1093/cjres/rsr034

Born, B. \& Purcell, M. (2006). Avoiding the Local Trap: Scale and Food Systems in Planning Research. Journal of Planning Education and Research 26(2), 195-207. https://doi.org/10.1177/0739456X06291389

Bornemann, B., \& Weiland, S. (2019). Empowering people-democratising the food system? Exploring the democratic potential of food-related empowerment forms. Politics and Governance, 7(4), 105-118. https://doi.org/10.17645/pag.v7i4.2190

Bradley, K., \& Galt, R. E. (2014). Practicing food justice at Dig Deep Farms and Produce, East Bay Area, California: Self-determination as a guiding value and intersections with foodie logic. Local Environment, 19(2), 172-186. https://doi.org/10.1080/13549839.2013.790350

Bródy, L. S., \& de Wilde, M. (2020). Cultivating food or cultivating citizens? On the governance and potential of community gardens in Amsterdam. Local Environment, 25(3), 243-257. https://doi.org/10.1080/13549839.2020.1730776

Brown, A. (2002). Farmers market research 1940-2000: An inventory and review. American Journal of Alternative Agriculture, 17(4), 167-176. 
Bunkus, R., Soliev, I., \& Theesfeld, I. (2020). Density of resident farmers and rural inhabitants' relationship to agriculture: operationalizing complex social interactions with a structural equation model. Agriculture and Human Values, 37(1), 47-63. https://doi.org/10.1007/s10460-019-09966-7

Byker, C., Shanks, J., Misyak, S., \& Serrano, E. (2012). Characterizing farmers' market shoppers: A literature review. Journal of Hunger and Environmental Nutrition, 7(1), 38-52. https://doi.org/10.1080/19320248.2012.650074

Cameron, A. (2007). Farmers' markets as small business incubators and safety nets: Evidence from New Zealand. International Journal of Entrepreneurial Behaviour and Research, 13(6), 367-379. https://doi.org/10.1108/13552550710829179

Canal Vieira, L., Serrao-Neumann, S., \& Howes, M. (2019). Local action with a global vision: The transformative potential of food social enterprises in Australia. Sustainability, 11(23), 6756. https://doi.org/10.3390/su11236756

Carolan, M. (2017). More-than-active food citizens: A longitudinal and comparative study of alternative and conventional eaters. Rural Sociology, 82(2), 197-225. https://doi.org/10.1111/ruso.12120

Chiffoleau, Y., Millet-Amrani, S., Rossi, A., Rivera-Ferre, M. G., \& Merino, P. L. (2019). The participatory construction of new economic models in short food supply chains. Journal of Rural Studies, 68(2019), 182-190. https://doi.org/10.1016/i.jrurstud.2019.01.019

Christensen, B., \& Phillips, R. (2016). Local food systems and community economic development through the lens of theory. Community Development, 47(5), 638-651. https://doi.org/10.1080/15575330.2016.1214609

Chung, K., Kirkby, R. J., Kendell, C., \& Beckwith, J. A. (2005). Civic agriculture: Does public space require public ownership? Culture and Agriculture 27(2), 99-108. https://doi.org/10.1525/cag.2005.27.2.99

Clark, J. K., \& Record, M. (2017). Local capitalism and civic engagement: The potential of locally facing firms. Public Administration Review, 77(6), 875-887. https://doi.org/10.1111/puar.12791

Colasanti, K. J. A., Conner, D. S., \& Smalley, S. B. (2010). Understanding barriers to farmers' market patronage in Michigan: Perspectives from marginalized populations. Journal of Hunger and Environmental Nutrition, 5(3), 316-338. https://doi.org/10.1080/19320248.2010.504097

Cone, C. A., \& Myhre, A. (2000). Community-supported agriculture: A sustainable alternative to industrial agriculture? Human Organization, 59(2), 187-197. https://doi.org/10.17730/humo.59.2.715203t206g2j153

Cox, R., Holloway, L., Venn, L., Dowler, L., Hein, J. R., Kneafsey, M., \& Tuomainen, H. (2008). Common ground? Motivations for participation in a community-supported agriculture scheme. Local Environment, 13(3), $203-218$. https://doi.org/10.1080/13549830701669153

Crossan, J., Cumbers, A., McMaster, R., \& Shaw, D. (2016). Contesting neoliberal urbanism in Glasgow's community gardens: The practice of DIY citizenship. Antipode, 48(4), 937-955. https://doi.org/10.1111/anti.12220

Cumbers, A., Shaw, D., Crossan, J., \& McMaster, R. (2018). The work of community gardens: Reclaiming place for community in the city. Work, Employment and Society, 32(1), 133-149. https://doi.org/10.1177/0950017017695042

Cvijanović, D., Ignjatijević, S., Tankosić, J. V., \& Cvijanović, V. (2020). Do local food products contribute to sustainable economic development? Sustainability, 12(7), 2847. https://doi.org/10.3390/su12072847

DeLind, L. B. (2002). Place, work, and civic agriculture: Common fields for cultivation. Agriculture and Human V alues, 19(3), 217-224. https://doi.org/10.1023/A:1019994728252

DeLind, L. B. (2011). Are local food and the local food movement taking us where we want to go? Or are we hitching our wagons to the wrong stars? Agriculture and Human V alues, 28(2), 273-283. https://doi.org/10.1007/s10460-010-9263-0

DeLind, L. B., \& Bingen, J. (2008). Place and civic culture: Re-thinking the context for local agriculture. Journal of Agricultural and Environmental Ethics, 21(2), 127-151. https://doi.org/10.1007/s10806-007-9066-5

Deller, S. C., Lamie, D., \& Stickel, M. (2017). Local foods systems and community economic development. Community Development, 48(5), 612-638. https://doi.org/10.1080/15575330.2017.1373136

Dunlap, R., Harmon, J., \& Camp, B. H. (2020). Cultivating self-reliance: Participation in urban agriculture as civil leisure. Annals of Leisure Research, 231(4), 530-543. https://doi.org/10.1080/11745398.2019.1613668

DuPuis, E. M., \& Gillon, S. (2009). Alternative modes of governance: Organic as civic engagement. Agriculture and Human Values, 26(1), 43-56. https://doi.org/10.1007/s10460-008-9180-7 
DuPuis, E. M., \& Goodman, D. (2005). Should we go "home" to eat?: Toward a reflexive politics of localism. Journal of Rural Studies, 21(3), 359-371. https://doi.org/10.1016/j.jrurstud.2005.05.011

DuPuis, E. M., Goodman, D., \& Harrison, J. (2006). Just values or just value? Remaking the local in agro-food studies. Research in Rural Sociology and Development, 12 (2006), 241-268. https://doi.org/10.1016/S1057-1922(06)12010-7

Feenstra, G. W., Lewis, C. C., Hinrichs, C. C., Gillespie, G. W., \& Hilchey, D. (2003). Entrepreneurial outcomes and enterprise size in US retail farmers' markets. American Journal of Alternative Agriculture, 18(1), 46-55. https://doi.org/10.1079/AJAA2003046

Feldmann, C., \& Hamm, U. (2015). Consumers' perceptions and preferences for local food: A review. Food Quality and Preference, 40(A), 152-164. https://doi.org/10.1016/j.foodqual.2014.09.014

Firth, C., Maye, D., \& Pearson, D. (2011). Developing “community” in community gardens. Local Environment, 16(6), 555-568. https://doi.org/10.1080/13549839.2011.586025

Flora, C., \& Bregendahl, C. (2012). Collaborative community-supported agriculture: Balancing community capitals for producers and consumers. The International Journal of Sociology of Agriculture and Food, 19(3), 329-346. https://doi.org/10.48416/ijsaf.v19i3.208

Fowler, I. A. (1958). Local industrial structures, economic power, and community welfare. Social Problems, 6(1), 41-51. https://doi.org/10.2307/798994

Furman, C., Roncoli, C., Nelson, D. R., \& Hoogenboom, G. (2014). Growing food, growing a movement: Climate adaptation and civic agriculture in the Southeastern United States. Agriculture and Human Values, 31(1), 69-82. https://doi.org/10.1007/s10460-013-9458-2

Galt, R. E., Bradley, K., Christensen, L., Fake, C., Munden-Dixon, K., Simpson, N.,. . Soelen Kim, J., (2017). What difference does income make for community supported agriculture (CSA) members in California? Comparing lower-income and higher-income households. Agriculture and Human Values, 34(2), 435-452. https://doi.org/10.1007/s10460-016-9724-1

Galt, R. E., Bradley, K., Christensen, L., \& Munden-Dixon, K. (2018). Exploring member data for community supported agriculture (CSA) in California: Comparisons of former and current CSA members. Data in Brief, 21, 2082-2088. https://doi.org/10.1016/i.dib.2018.11.045

Galt, R. E., Bradley, K., Christensen, L. O., \& Munden-Dixon, K. (2019). The (un)making of “CSA people”: Member retention and the customization paradox in community supported agriculture (CSA) in California. Journal of Rural Studies, 65(2019), 172-185. https://doi.org/10.1016/j.jrurstud.2018.10.006

Gillespie, G., Hilchey, D., Hinrichs, C., \& Feenstra, G. (2006). Farmers' markets as keystones in rebuilding local and regional food systems. In C. C. Hinrichs \& T. A. Lyson (Eds.), Remaking the North American food system: Strategies for sustainability (pp. 65-83). Lincoln: University of Nebraska Press.

Godette, S. K., Beratan, K., \& Nowell, B. (2015). Barriers and facilitators to local food market development: A contingency perspective. Journal of Agriculture, Food Systems, and Community Development, 5(3), 79-96. http://dx.doi.org/10.5304/jafscd.2015.053.012

Goldschmidt, W. (1978). As you sow. Montclair, NJ: Allanheld, Osmun.

Guptill, A., Larsen, D., Welsh, R., \& Kelly, E. (2018). Do affluent urban consumers drive direct food sales in the Northeast United States? A three-part analysis. Journal of Agriculture, Food Systems, and Community Development, 8(2), 7386. https://doi.org/10.5304/jafscd.2018.082.005

Guthman, J. (2003). Fast food/organic food: Reflexive tastes and the making of 'yuppie chow.' Social and Cultural Geography, 4(1), 45-58. https://doi.org/10.1080/1464936032000049306

Guthman, J. (2008). Bringing good food to others: Investigating the subjects of alternative food practice. Cultural Geographies, 15(4), 431-447. https://doi.org/10.1177/1474474008094315

Guthman, J. (2008). 'If they only knew': Color blindness and universalism in California alternative food institutions. The Professional Geographer, 60(3), 387-397. https://doi.org/10.1080/00330120802013679

Guthman, J. (2011). Weighing in: Obesity, food justice, and the limits of capitalism. Berkeley: University of California Press. 
Hasanov, M., Zuidema, C., \& Horlings, L. G. (2019). Exploring the role of community self-organisation in the creation and creative dissolution of a community food initiative. Sustainability, 11(11), 3170. https://doi.org/10.3390/su11113170

Hassanein, N. (2003). Practicing food democracy: A pragmatic politics of transformation. Journal of Rural Studies, 19(1), 77-86. https://doi.org/10.1016/S0743-0167(02)00041-4

Hayes, M. N., \& Olmstead, A. L. (1984). Farm size and community quality: Arvin and Dinuba revisited. American Journal of Agricultural Economics, 66(4), 430-436. https://doi.org/10.2307/1240921

Hinrichs, C. C. (2000). Embeddedness and local food systems: Notes on two types of direct agricultural market. Journal of Rural Studies, 16(3), 295-303. https://doi.org/10.1016/S0743-0167(99)00063-7

Hinrichs, C. C. (2003). The practice and politics of food system localization. Journal of Rural Studies, 19(1), 33-45. https://doi.org/10.1016/S0743-0167(02)00040-2

Hinrichs, C. C., Gillespie, G. W., \& Feenstra, G. W. (2004). Social learning and innovation at retail farmers' markets. Rural Sociology, 69(1), 31-58. https://doi.org/10.1526/003601104322919892

Hughes, D. W., \& Isengildina-Massa, O. (2015). The economic impact of farmers' markets and a state level locally grown campaign. Food Policy, 54, 78-84. https://doi.org/10.1016/j.foodpol.2015.05.001

Humphries, S. (2001). Who's afraid of the big, bad firm: The impact of economic scale on political participation. American Journal of Political Science, 45(3), 678. https://doi.org/10.2307/2669245

Irwin, M., \& Tolbert, C. (1997). How to build strong home towns. American Demographics, 19(2), 43-53.

Irwin, M., Tolbert, C., \& Lyson, T. (1999). There's no place like home: Nonmigration and civic engagement. Environment and Planning A, 31(12), 2223-2238. https://doi.org/10.1068/a312223

Janssen, B. (2010). Local food, local engagement: Community-supported agriculture in eastern Iowa. Culture \& Agriculture, 32(1), 4-16. https://doi.org/10.1111/j.1556-486X.2010.01031.x

Jarosz, L. (2011). Defining world hunger: Scale and neoliberal ideology in international food security policy discourse. Food, Culture and Society, 14(1) 117-139. https://doi.org/10.2752/175174411X12810842291308

Johnston, J. (2008). The citizen-consumer hybrid: Ideological tensions and the case of Whole Foods Market. Theory and Society, 37(3), 229-270. https://doi.org/10.1007/s11186-007-9058-5

Kingsley, J., Foenander, E., \& Bailey, A. (2019). "You feel like you're part of something bigger": Exploring motivations for community garden participation in Melbourne, Australia. BMC Public Health, 19, 745. https://doi.org/10.1186/s12889-019-7108-3

Kirwan, J., \& Maye, D. (2013). Food security framings within the UK and the integration of local food systems. Journal of Rural Studies, 29(2013), 91-100. https://doi.org/10.1016/j.jrurstud.2012.03.002

Lang, T. (1999). Food policy for the 21st century: Can it be both radical and reasonable? In M. Koc, R. MacRae, L. J. A. Mougeot, \& J. Welsh, (Eds.), For hunger-proof cities: Sustainable urban food systems (pp. 216-224). Ottawa: International Development Research Centre.

Lass, D., Bevis, A., Hendrickson, J., \& Ruhf, K. (2001). Community supported agriculture entering the 21st century: Results from the 2001 national survey. Retrieved from https://cias.webhosting.cals.wisc.edu/wp-content/uploads/sites/194/2008/07/csa survey 011.pdf

Lee, M. R. (2008). Civic community in the hinterland: Toward a theory of rural social structure and violence. Criminology, 46(2), 447-48. https://doi.org/10.1111/j.1745-9125.2008.00115.x

Lee, M. R. (2010). The protective effects of civic communities against all-cause mortality. Social Science and Medicine, 70(11), 1840-1846. https://doi.org/10.1016/j.socscimed.2010.02.020

Lee, M. R., \& Thomas, S. A. (2010). Civic community, population change, and violent crime in rural communities. Journal of Research in Crime and Delinquency, 47(1), 118-147. https://doi.org/10.1177/0022427809348907

Lev, L., Brewer, L., \& Stephenson, G. (2003). How do farmers' markets affect neighboring businesses? (Oregon Small Farms Technical Report No. 16). Oregon State University Extension. Retrieved from https://smallfarms.oregonstate.edu/sites/agscid7/files/techreport16.pdf

Levkoe, C. Z. (2006). Learning democracy through food justice movements. Agriculture and Human Values, 23(1), 89-98. https://doi.org/10.1007/s10460-005-5871-5 
Liu, P., Gilchrist, P., Taylor, B., \& Ravenscroft, N. (2017). The spaces and times of community farming. Agriculture and Human V alues, 34(2), 363-375. https://doi.org/10.1007/s10460-016-9717-0

Lombardi, A., Migliore, G., Verneau, F., Schifani, G., \& Cembalo, L. (2015). Are “good guys" more likely to participate in local agriculture? Food Quality and Preference, 45, 158-165. https://doi.org/10.1016/j.foodqual.2015.06.005

Low, S. A., Adalja, A., Beaulieu, E., Key, N., Martinez, S., Melton, A., ... Jablonski, B. B. R. (2015). Trends in U.S. local and regional food systems (AP-068). Washington, D.C.: U.S. Department of Agriculture, Economic Research Service. Retrieved from https://www.ers.usda.gov/webdocs/publications/42805/51173 ap068.pdf

Low, S. A., \& Vogel, S. (2011). Direct and intermediated marketing of local foods in the United States (Report No. ERR-128). Washington, D.C.: USDA Economic Research Service. Retrieved from https://doi.org/10.2139/ssrn.2114361

Lyson, T. A. (2004). Civic agriculture: Reconnecting farm, food, and community. Lebanon, N.H.: Tufts University Press.

Lyson, T. A. (2005). Civic agriculture and community problem solving. Culture and Agriculture, 27(2), 92-98. https://doi.org/10.1525/cag.2005.27.2.92

Lyson, T. A. (2006). Big business and community welfare. American Journal of Economics and Sociology, 65(5), $1001-1023$. https://doi.org/10.1111/i.1536-7150.2006.00489.x

Lyson, T. A., \& Guptill, A. (2004). Commodity agriculture, civic agriculture and the future of U.S. farming. Rural Sociology, 69(3), 370-385. https://doi.org/10.1526/0036011041730464

Lyson, T. A., \& Tolbert, C. M. (1996). Small manufacturing and nonmetropolitan socioeconomic well-being. Environment and Planning A, 28(10), 1779-1794. https://doi.org/10.1068/a281779

Lyson, T. A., \& Tolbert, C. M. (2003). Civil society, civic communities, and rural development. In D. L. Brown, L. E. Swanson, \& A. Brown (Eds.), Challenges for rural America in the twenty-first century (pp. 228-238). Penn State University Press. https://doi.org/10.5325/j.ctv14gp32b.23

Lyson, T. A., Torres, R. J., \& Welsh, R. (2001). Scale of agricultural production, civic engagement, and community welfare. Social Forces, 80(1), 311-327. https://doi.org/10.1353/sof.2001.0079

Macias, T. (2008). Working toward a just, equitable, and local food system: The social impact of community-based agriculture. Social Science Quarterly, 89(5), 1086-1101. https://doi.org/10.1111/j.1540-6237.2008.00566.x

Martinez, M., Hand, M., DaPra, M., Pollack, S., Ralston, K., Smith, T., . . Newman, C. (2010). Local food systems: Concepts, impacts, and issues, (Report No. ERR-97). USDA Economic Research Service. Retrieved from https://www.ers.usda.gov/publications/pub-details/?pubid=46395

McGuirt, J. T., Jilcott Pitts, S. B., Ward, R., Crawford, T. W., Keyserling, T. C., \& Ammerman, A. S. (2014). Examining the influence of price and accessibility on willingness to shop at farmers' markets among low-income Eastern North Carolina women. Journal of Nutrition Education and Behavior, 46(1), 26-33. https://doi.org/10.1016/j.jneb.2013.06.001

McIvor, D. W., \& Hale, J. (2015). Urban agriculture and the prospects for deep democracy. Agriculture and Human Values, 32(4), 727-741. https://doi.org/10.1007/s10460-015-9588-9

Mencken, F. C., Smith, B., \& Tolbert, C. M. (2020). Self-employment and civic inclination. Sociological Perspectives, 63(5), 719-737. https://doi.org/10.1177/0731121419899386

Migliore, G., Caracciolo, F., Lombardi, A., Schifani, G., \& Cembalo, L. (2014). Farmers' participation in civic agriculture: The effect of social embeddedness. Culture, Agriculture, Food and Environment, 36(2), 105-117. https://doi.org/10.1111/cuag.12038

Mills, C. W., \& Ulmer, M. J. (1946). Small business and civic welfare: Report of the Smaller War Plants Corporation to the Special Committee to Study Problems of American Small Business. Washington, D.C.: U.S. Government Printing Office.

Mount, P. (2012). Growing local food: Scale and local food systems governance. Agriculture and Human Values, 29(1), 107-121. https://doi.org/10.1007/s10460-011-9331-0

Niewolny, K., Helms, J., Clark, S., Cotton, J., Jacobson, K., Grossman, J., ... Jacobsen, K. L. (2012). Sustainable agriculture education and civic engagement: The significance of community-university partnerships in the new agricultural paradigm. Journal of Agriculture, Food Systems, and Community Development, 2(3), 27-42. https://doi.org/10.5304/jafscd.2012.023.005 
Obach, B. K., \& Tobin, K. (2014). Civic agriculture and community engagement. Agriculture and Human Values, $31(2)$, 307-322. https://doi.org/10.1007/s10460-013-9477-z

O'Hara, J. K., \& C. Coleman. (2017). The impacts of the farmers market and local food promotion programs. Community Development, 48(5), 681-696. https://doi.org/10.1080/15575330.2017.1350729

O'Hara, J. K., \& Low, S. A. (2016). The influence of metropolitan statistical areas on direct-to-consumer agricultural sales of local food in the Northeast. Agricultural and Resource Economics Review, 45(3), 539-562. https://doi.org/10.1017/age.2016.7

O’Hara, S. U., \& Stagl, S. (2001). Global food markets and their local alternatives: A socio-ecological economic perspective. Population and Environment, 22(6), 533-554. https://doi.org/10.1023/A:1010795305097

Oldenburg, R. 1991. The great good place. New York: Paragon House

Olson, K. A. (2019). The town that food saved? Investigating the promise of a local food economy in Vermont. Local Environment, 24(1), 18-36. https://doi.org/10.1080/13549839.2018.1545753

Onozaka, Y., Nurse, G., Thilmany McFadden, D. (2010). Local food consumers: How motivations and perceptions translate to buying behavior. Choices: The Magazine of Food, Farm \& Resource Issues, 25(1), 7-12. Retrieved from https://www.choicesmagazine.org/magazine/article.php?article $=109$

Ostrom, M. R. (2008). Community supported agriculture as an agent of change: Is it working? In C. C. Hinrichs \& T. A. Lyson (Eds.), Remaking the North American food system: Strategies for sustainability (pp. 99-120). Lincoln: University of Nebraska Press.

Piore, M. J., \& Sabel, C. F. (1984). The second industrial divide. New York: Basic Books.

Polanyi, K. (1944). The great transformation. Boston: Beacon Press.

Polanyi, K. (1957). The economy as instituted process. In K. Polanyi, C. M. Arensberg, \& H. W. Pearson (Eds.), Trade and markets in the early empires, (pp. 243-270). Glencoe, IL: Free Press.

Pole, A., \& Gray, M. (2013). Farming alone? What's up with the "C" in community supported agriculture. Agriculture and Human Values, 30(1), 85-100. https://doi.org/10.1007/s10460-012-9391-9

Poulsen, M. N. (2017). Cultivating citizenship, equity, and social inclusion? Putting civic agriculture into practice through urban farming. Agriculture and Human V alues, 34(1), 135-148. https://doi.org/10.1007/s10460-016-9699-y

Prost, S. (2019). Food democracy for all? Developing a food hub in the context of socio-economic deprivation. Politics and Governance, 7(4), 142-153. https://doi.org/10.17645/pag.v7i4.2057

Putnam, R. (1994). What makes democracy work? National Civic Review, 82(2), 101-107. https://doi.org/10.1002/ncr.4100820204

Renting, H., Marsden, T. K., \& Banks, J. (2003). Understanding alternative food networks: Exploring the role of short food supply chains in rural development. Environment and Planning A, 35(3), 393-411. https://doi.org/10.1068/a3510

Renting, H., Schermer, M., \& Rossi, A. (2012). Building food democracy: Exploring civic food networks and newly emerging forms of food citizenship. The International Journal of Sociology of Agriculture and Food, 19(3), $289-307$. https://doi.org/10.48416/ijsaf.v19i3.206

Robinson, K. L., Lyson, T. A., \& Christy, R. D. (2002). Civic community approaches to rural development in the South: Economic growth with prosperity. Journal of Agricultural and Applied Economics, 34(2), 327-338. https://doi.org/10.22004/ag.econ.15468

Ross, N. J. (2006). How civic is it? Success stories in locally focused agriculture in Maine. Renewable Agriculture and Food Systems, 21(2), 114-123. https://doi.org/10.1079/RAF2005134

Rossi, J. D., Johnson, T. G., \& Hendrickson, M. (2017). The economic impacts of local and conventional food sales. Journal of Agricultural and Applied Economics, 49(4), 555-570. https://doi.org/10.1017/aae.2017.14

Rupasingha, A. (2017). Local business ownership and local economic performance: Evidence from US counties. Regional Studies, 51(5), 659-673. https://doi.org/10.1080/00343404.2015.1119264

Sadler, R. C., Gilliland, J. A., \& Arku, G. (2013). Community development and the influence of new food retail sources on the price and availability of nutritious food. Journal of Urban Affairs, 35(4), 471-491.

https://doi.org/10.1111/j.1467-9906.2012.00624.x 
Saldivar-Tanaka, L., \& Krasny, M. E. (2004). Culturing community development, neighborhood open space, and civic agriculture: The case of Latino community gardens in New York City. Agriculture and Human Values, 21 (4), $399-412$. https://doi.org/10.1023/B:AHUM.0000047207.57128.a5

Schmit, T. M., Jablonski, B. B. R., Minner, J., Kay, D., \& Christensen, L. (2017). Rural wealth creation of intellectual capital from urban local food system initiatives: Developing indicators to assess change. Community Development, 48(5), 639-656. https://doi.org/10.1080/15575330.2017.1354042

Schnell, S. M. (2010). Food with a farmer's face: Community-supported agriculture in the United States. Geographical Review, 97(4), 550-564. https://doi.org/10.1111/j.1931-0846.2007.tb00412.x

Schnell, S. M. (2013). Food miles, local eating, and community supported agriculture: Putting local food in its place. Agriculture and Human Values, 30(4), 615-628. https://doi.org/10.1007/s10460-013-9436-8

Schnell, S. M. (2016). Localism and food and nutrition security. In B. Pritchard, R. Ortiz, \& M. Shekar (Eds.), Routledge bandbook of peacebuilding (pp. 349-367). New York: Routledge.

Schugerensky, D. (2003). Three theses on citizenship learning and participatory democracy. Retrieved in May 2020 from http://fcis.oise.utoronto.ca/ daniel_schugurensky/lclp/lclp_intro.html.

Sharp, J., Imerman, E., \& Peters, G. (2002). Community supported agriculture (CSA): Building community among farmers and non-farmers. Journal of Extension, 40(3), Art. 3FEA3. Retrieved from https://archives.joe.org/joe/2002june/a3.php

Shideler, D., Bauman, A., Thilmany, D., \& Jablonski, B. B. R. (2018). Putting local food dollars to work: The economic benefits of local food dollars to workers, farms and communities. Choices: The Magazine of Food, Farm \& Resource Issues, 33(3), 1-8. Retrieved from https://www.jstor.org/stable/26583606

Siegner, A. B., Acey, C., \& Sowerwine, J. (2020). Producing urban agroecology in the East Bay: From soil health to community empowerment. Agroecology and Sustainable Food Systems, 44(5), 566-593.

https://doi.org/10.1080/21683565.2019.1690615

Smit, J., \& Bailkey, M. (2006). Urban agriculture and the building of communities. In R. van Veenhuizen (Ed.), Cities farming for the future: Urban agriculture for green and productive cities (pp. 145-170). Leusde: RUAF Foundation, IIRR and IDRC. Retrieved from https://citeseerx.ist.psu.edu/viewdoc/download?doi=10.1.1.124.4555\&rep=rep1\&type=pdf

Snyder, H. (2019). Literature review as a research methodology: An overview and guidelines. Journal of Business Research, 104, 333-339. https://doi.org/10.1016/i.jbusres.2019.07.039

Sonnino, R. (2013). Local foodscapes: Place and power in the agri-food system. Acta Agriculturae Scandinavica, Section B Soil \& Plant Science, 63(Suppl. 1), 2-7. https://doi.org/10.1080/09064710.2013.800130

Stroope, S., Franzen, A. B., Tolbert, C. M., \& Mencken, F. C. (2014). College graduates, local retailers, and community belonging in the United States. Sociological Spectrum, 34(2), 143-162. https://doi.org/10.1080/02732173.2014.878612

Sullivan, W. C., Kuo, F. E., \& DePooter, S. F. (2004). The fruit of urban nature: Vital neighborhood spaces. Environment \& Behavior, 36(5), 678-700. https://doi.org/10.1177/0193841X04264945

Sumner, J., Mair, H., \& Nelson, E. (2010). Putting the culture back into agriculture: Civic engagement, community and the celebration of local food. International Journal of Agricultural Sustainability, 8(1-2), 54-61.

https://doi.org/10.3763/ijas.2009.0454

Swenson, D. (2009). Investigating the potential economic impacts of local foods for southeast Iowa (Leopold Center Publications and Papers No. 66). Retrieved from https://lib.dr.iastate.edu/leopold pubspapers/66/

Tegtmeier, E. M., \& Duffy, M. (2005). Community supported agriculture (CSA) in the Midwest United States: A regional characterization (Leopold Center Publications and Papers No. 151). Retrieved from https://lib.dr.iastate.edu/leopold pubspapers/151

Thilmany, D., Bond, C. A., \& Bond, J. K. (2008). Going local: Exploring consumer behavior and motivations for direct food purchases. American Journal of Agricultural Economics, 90(5), 1303-1309. https://doi.org/10.1111/j.1467-8276.2008.01221.x

Tolbert, C. M. (2005). Minding our own business: Local retail establishments and the future of Southern civic community. Social Forces, 83(4), 1309-1328. https://doi.org/10.1353/sof.2005.0084 
Tolbert, C. M., Irwin, M. D., Lyson, T. A., \& Nucci, A. R. (2002). Civic community in small-town America: How civic welfare is influenced by local capitalism and civic engagement. Rural Sociology, 67(1), 90-113. https://doi.org/10.1111/j.1549-0831.2002.tb00095.x

Tolbert, C. M., Lyson, T. A., \& Irwin, M. D. I. (1998). Local capitalism, civic engagement, and socioeconomic wellbeing. Social Forces, 77(2), 401-427. https://doi.org/10.2307/3005533

Tolbert, C. M., Mencken, F. C., Blanchard, T. C., \& Li, J. (2016). American civic community over space and time. In F. Howell, J. Porter, \& M. Stephen (Eds.), Recapturing space: New middle-range theory in spatial demography (pp. 11-36). Cham, Switzerland: Springer. https://doi.org/10.1007/978-3-319-22810-5 12

Torraco, R. J. (2005). Writing integrative literature reviews: Guidelines and examples. Human Resource Development Review, 4(3), 356-367. https://doi.org/10.1177/1534484305278283

Tornaghi, C. (2016). Urban agriculture in the food-disabling city: (Re)defining urban food justice, reimagining a politics of empowerment. Antipode, 49(3), 781-801. https://doi.org/10.1111/anti.12291

Trauger, A., Sachs, C., Barbercheck, M., Brasier, K., \& Kiernan, N. E. (2010). "Our market is our community”: Women farmers and civic agriculture in Pennsylvania, USA. Agriculture and Human V alues, 27(1), 43-55. https://doi.org/10.1007/s10460-008-9190-5

Trivette, S. A. (2017). Invoices on scraps of paper: Trust and reciprocity in local food systems. Agriculture and Human Values, 34(3), 529-542. https://doi.org/10.1007/s10460-016-9738-8

U.S. Bureau of Labor Statistics. (2016). Entrepreneurship and the economy. Retrieved from https://www.bls.gov/bdm/entrepreneurship/entrepreneurship.htm

U.S. Department of Agriculture Economic Research Service (USDA ERS). (2014). Number of U.S. farmers' markets continues to rise. Retrieved from https:/ / www.ers.usda.gov/data-products/chart-gallery/gallery/chart-detail/?chartId=77600

U.S. Small Business Administration (2019). Size standards. Retrieved from https://www.sba.gov/federal-contracting/contracting-guide/size-standards

Wells, B. L., \& Gradwell, S. (2001). Gender and resource management: Community supported agriculture as caringpractice. Agriculture and Human Values, 18(1), 107-119. https://doi.org/10.1023/A:1007686617087

Wittman, H., Beckie, M., \& Hergesheimer, C. (2012). Linking local food systems and the social economy? Future roles for farmers' markets in Alberta and British Columbia. Rural Sociology, 77(1), 36-61. https://doi.org/10.1111/i.1549-0831.2011.00068.x

Wolf, M. M., \& Berrenson, E. (2003). A comparison of purchasing behaviors and consumer profiles at San Luis Obispo's Thursday night farmers' market: A case study. Journal of Food Distribution Research, 34(1), 107-122. https://doi.org/10.22004/ag.econ.27936

Zepeda, L., \& Nie, C. (2012). What are the odds of being an organic or local food shopper? Multivariate analysis of US food shopper lifestyle segments. Agriculture and Human Values, 29(4), 467-480. https://doi.org/10.1007/s10460-012-9364-z

Zoll, F., Specht, K., Opitz, I., Siebert, R., Piorr, A., \& Zasada, I. (2018). Individual choice or collective action? Exploring consumer motives for participating in alternative food networks. International Journal of Consumer Studies, 42(1), 101110. https://doi.org/10.1111/ijcs.12405 